\title{
近代における雁木通りの整備過程と衰退過程 \\ THE ARRANGEMENT PROCESS AND DISAPPEARANCE PROCESS \\ OF THE GANGI ARCADE IN THE MODERN AGES
}

\author{
菅原邦 生*，波多野 純** \\ Kunio SUGAHARA and Jun HATANO
}

\begin{abstract}
A Study on the Arrangement process and Disappearance process of the Gangi Arcade in the Modern Ages.
\end{abstract}

1. In the early part of the Meiji Era the Gangi Arcade were arranged under various instructions from the prefectural governments that aimed at securing the alley function. Arrangement process of the Gangi Arcade had two types.

(1) In the early part of the Meiji Era the Gangi Arcade were arranged in public land.

(2) The Gangi Arcade had been arranged in private land since then.

2. The Gangi Arcade waned or disappeared. It was the following reasons.

(1) Conflagrations (Aomori, Hachinohe, Niigata),

(2) The urban planning after the Second World War (Hirosaki).

keywords:Gangi, Gangi arcade, Komise, Modern 㕍木, 雁木通り, 小店, 近代

I .はじめに

碓木通りは，深雪地域における歩行者用の通路であり，睢木を設 けた町家が連続することで形成される。

前稿"においては，近世における㕍木通りの建設整備過程につい て検討し，以下の点を明らかにした。

䧹木通りの建設が確認できる最初の例は，元和3年 (1617)～8年の 長岡であり，その後，各地に建設された。

倠木通りの成立過程には，二つの事例が指摘できる。

(1)城下町建設と同時期に，质木通りが建設された場合には，藩命 により，屋敷地に政策的に建設された(長岡の表町・上田町)。

(2)城下町建設後に雁木通りが建設された場合には，道路上に建設 された(長岡の裹町，高田など)。これは，城下町建設後では， 屋敷地に雁木を建設するのが困難なためである。さらに，道路 上に建設された㕍木通りのうち，後年雁木下が私有地化した 例(高田)がある。これは，㷳木下の町人による占有化を藩が追 認したものである。

䧹木の形式には，落し式と造り込み式があり，当初の形式は落し 式であったが，後年，䧹木下の私有地化にともない，碓木部分にお ける，府子二階あるいは二階の建設により，造り込み式雄木が建設 された(高田)。

近代においては，通路機能の確保を目的に，雁木の囲い込みが撤
去され，さらに㕍木下が哺装された。戦後，画一的な都市計画や防 火の観点から，雁木通りは衰退消隇したとされるが，具体的な検討 には至っていない。

本稿では，近代における䧹木通りの整備過程と，その後の衰退過 程について, 弘前・青箖・八戸・新潟・長岡・高田・系魚川を事例 "に検討する。

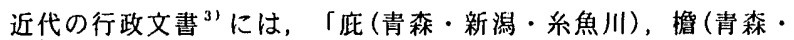
新潟)，相(弘前)，軒下(弘前・青森・新潟)，小見世(青箖)，小店 (青森)」の呼称が確認できる。これらの呼称は，近世においても用 いられた場合が多ぐ，いずれも雁木と同義である。とくに新潟と 青森では，指示の内容によって，雁木の呼称が使い分けられた。た とえば新潟では，雁木そのものを対象とした場合は「仳」あるいは

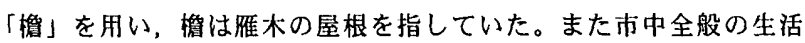
改善を目的とし，その中で隺木についても取りあつかう場合は， 「軒下」を用いた。さらに青森でも，同様の傾向が見られる。

\section{II . 各都市における㕍木通りの整備過程と衰退過程} 1)弘前における小店の整備と利用

弘前は，明治4年 (1871) 7月に津軽藩が廃藩となり，同年9月 23 日 に県庁が青森に移転したことにより，商工業が衰退し，近代化が遅 れた。実際に近代的な都市整備が開始されたのは，鉄道が開通し，
* 日本工業大学工学部建築学科 大学院生 $\cdot$ 工修

** 日本工業大学工学部建築学科 教授. 工博
Graduate Student, Dept. of Architecture, Faculty of Engineering, Nippon Institute of Technology, M. Eng.

Prof., Dept. of Architecture, Faculty of Engineering, Nippon Institute of Technology, Dr. Eng. 
第八師団が設置された明治 20 年代後半である ${ }^{5)}$ 。明治 22 年 (1889) 4 月には，市制を施行した。

(1)店の便所の微毒 明治5年 (1872)2月10日に，『陃習习洗脱可致 旨，左之通相達候事』との布達 ${ }^{6)}$ があった。同布達には，

亁下二不浄場习設クヘカラス

とある。さらに，同年9月の布令" においても，小店の便所の撤去 を再度指示している。同布令には，「文明ノ日二当リ，他府県二八 曾テ無之辺鄙ノ䧣習，実二恥ズべキ事」とある。小店に設けられた 便所は，恶習として，撤去が指示さ れ，邀卒を町に巡回させ，指導徽底 がされた

2小店の副用 明治24年 (1891)に， 土手町西側に開店した「角み呉服店」 の, 古写真にみると (図-1) ${ }^{91}$ ，3階 建の洋風建等で，主屋前面には，落 し式の小店が設けられている。小店 と道路の境にはカラス戸が建込まれ ており，小店下は店舗空間として， 利用されていたものと考えられる。

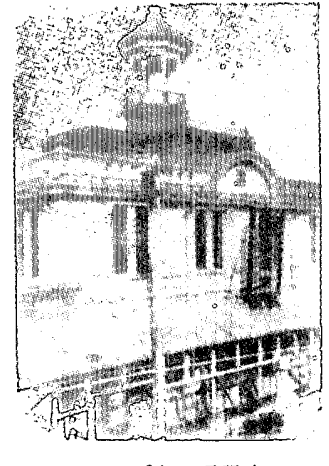

図- 1 「角み呉服店」
土手町西㑡は，明治27年 (1894)の，弘前一青禁間の鉄道開通によ り，町の北側に停車場が設置され，さらに，第八師団の，将葆用官

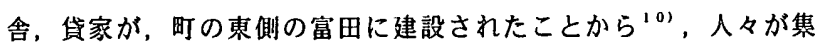
まり睓買力が增大したため，明治 20 年代後半以降，商業地域として

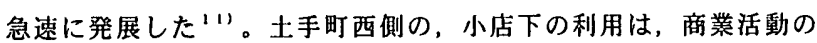
活発化にともない，店舖空間の拢大を必要としたためであろう。

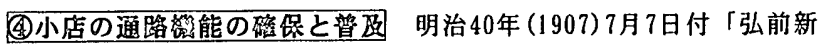
問」 ${ }^{21} に は$,

土手町に入れば，両側の廂自由に通られる様に造られてあるの で頗る便利である

とある。土手町においては，小店は店舖空間として利用されながら も，通路機能が保たれていたものと考えられる。

さらに，大正5年(1916)の『青森県弘前市俯瞰地図』 ${ }^{33}$ には，市 内の，道路に沿った商店とその店先が，鳥瞰的に描かれ，落し式の 小店が町に普及している様子が分る。

(5小店通りの空遍と消涚 その後，弘前の小店通りは，戦後の都市 計画により衰退した。都市計画が本格化したのは，昭和38年 (1963) であり 14)，昭和47年 (1972)の『弘前市都市計画図』 ${ }^{15)}$ にされば, 搪蝠予定の道路は，明治時代末期から大正時代初期にかけて小店通 りが設けられていた地域 ${ }^{16)}$ とほぼ致する。また，払幅に際して は，小店下の一部あるいは全部を道路とすることで，道幅を抾幅し た"7。よって都市計画にともなう道路搪幅により，小店通りが衰 退したと考えられる。

以上のように弘前においては，明治5年 (1872)に小店の便所の撤 去が指示され，小店が整備された。明治時代中頃には，商丵活動の 活発化にともない，小店柱にカラス戸を取付け，小店を店哺空間と して利用する傾向が強まった。その後，弘前の小店通りは，戦後の 都市計画にともなう道路抾幅により，衰退した。

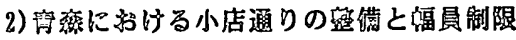

青薪は，北海道開拓のための開拓移住者の渡航地であった ${ }^{18)}$ 。 そのため船舶の往来が領䇣となり，明治 3 年 (1870)には近代的な都
市整備が開始された ${ }^{19)}$ 。明治4年（1871）には，県庁所在地となり， 明治31年(1898) 4 月に，市制を施行した ${ }^{20)}$ 。

(1)店の監调 明治5年 (1872)2月13日の『村井旧記』“"には，

追々馬車人力車等相用ふはずにつき，道路は勿論軒下等まで砂

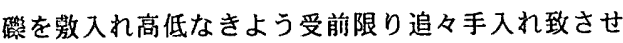
とあり，小店は，公道と同等の通路機能が求められた。さらに，同 記録には。

軒下に不浄場を設くべからず

とある。これらの整備の目的は, 都市整備の本格化に際し, 恵習と された小店の便所を撤去することにある2

明治5年 (1872)5月21日発行『青森実地明細絵図』 ${ }^{23)}$ には, 商占 とその店先が，鳥瞰図として描かれ，落し式の小店が普及している。

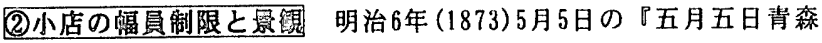
町小店下牛馬往来ノ儀二付布令候事』 ${ }^{24)}$ には，

五月五日青森町小店下牛馬往来ノ儀二付布令候事

(中略)

當町ノ如ク牛馬 ルヨ見ス，且已前ノ如ク板或八延等二テ取囲七候テハ，大二市

㢆ノ観光习損シ行圭當町不繁栄ノ地二相成

とあり，明治6年 (1873)には，牛馬が小店を往来し，人々の往来の 蚄げとなっていた。さらに，小店を板。むしろなどで囲うことは， 景観上好ましくないとする方針が示された。さらに，

今後新家作ノ者共八，小店三尺习限リ造作致シ とあり，新箱の場合の小店の幅員を，3尺に制限した。また，小店 先には，むしろ・あし・すのこなどを設けず，䁔穊，障子を用いる こととされた ${ }^{25}$ 。

同年7月の「七月欠日當市中取締方之儀，是迄追々布令二及置侯 處，今般嚺卒习置キ，尚又取締致候二付，左之修々堅ク相守可申事」 26)には，

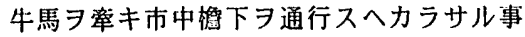

とあり，小店の牛馬の往来を等じた。さらに，

市中往来左右之溝ヨリ前へ庇 $习$ 出又間数事

とあり，道路上への小店の張り出しを禁じた(図ー2)。また，同月

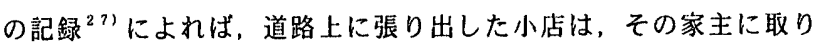
払わせた。

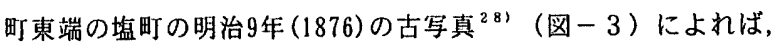
落し式の小店が確認でき，その屋根は石笵板苜である。また，小店 が清より前の道路上にはみ出していないことから，指示は，守られ ていたことが分る。

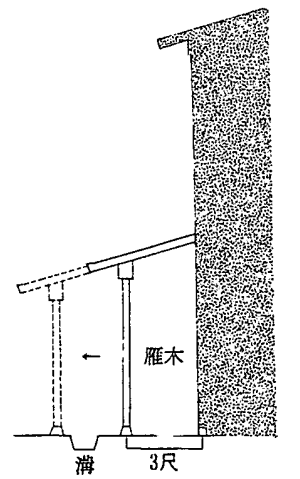

図-2 小店の道路上への張り山し

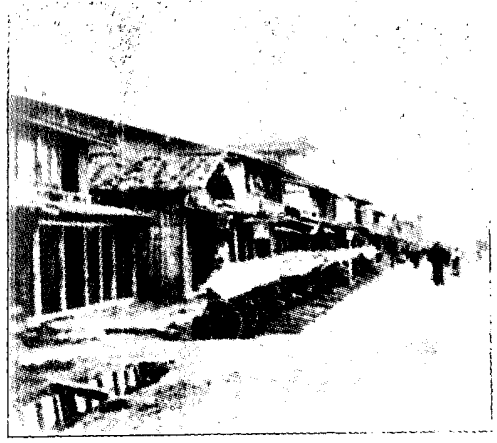

図 -3 明治 9 年 $(1876)$ の篮町の小店 
(3小店通りの裹退と消隇 青森は，明治43年 (1910)5月3日の大火に より，ほとんどの小店通りが焼失した ${ }^{291}$ 。青森県知事武田千代三郎 法，大火後の防火対策として，同年5月17日に，青森市建策取締規 則を発布した ${ }^{301}$ 。同規則の第19条には，

店頭には小見世を設くべからず，但し一定の区域内に於て各戸 同一の構造に依り不燃物質を以て之を建設せんとする時は特に 之を許可することあるべし

とあり，小店の建設を原則的に禁止している。ただし，統一して不 燃材で作る場合には許可されることもあった。それを受けて，同年， 青森市長工藤卓爾は，市債40万円を投じて実際の復旧を行った ${ }^{31}$ 。 同対策の事業計画の中には到，

本市の道路幅は，綐町通りは浜町に限り十二間其他は八間，横 町通りは六間で，しかも従来小店敷地として両側三尺つ〉使用 せしめていたのを，火災後は全部道路敷と改め，両側に雨水排 清を改修

とある。「従来小店敷地として両側三尺つ〉使用せしめ」とあるこ とから，小店は，大火以前において，公有地である道路上に建設さ れていた。

明治 43 年 (1910)の大火後には，米町などにおいて，小店の㙭根を

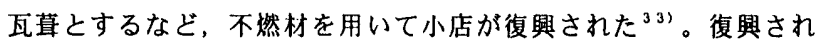
た小店通りは，戦災(昭和 20 年・1945)により消减した ${ }^{34) 。 ~}$

以上のように青森においては, 明治5年 (1872)に，小店は，公道 と同等の機能が求められた。その後, 明治 43 年 (1910)の大火により, ほとんどの小店通りが焼失した。大火後，小店通りの一部は不㜣材 で復興されたが，戦災により消隇した。また明治 43 年 (1910)の記録 によれば，小店は，公有地である道路上に建設されていた。

3)八戸における落し式の小店通り

八戸は, 明治24年 (1891)の東北本線の開通, 大正13年 (1924)の八 戸線の開通により，海岸部の町村と関係を深め，昭和 4 年 (1929)に 海岸部の小中野町・湊町・鲛村などの町村を合併し，市制を施行し $\star^{35)}$ 。

(1明治期の小店通りの景园 八戸は，明治20年代の表町の古写真 ${ }^{38)}$ (図-4)によれば，板葷の落し式の小店が設けられていた。小店の 前には幅広の水路があり，小店と道路の間は，板橋で繋がれていた。 さらに，明治40年代の表町の古写真 ${ }^{311}$ によれば，小店先には，か け障子・戸障子が設けられていた。このかけ障子は，「しとみ」・ しとよめと呼称された ${ }^{381}$ 。

(2大正期の小店通りの景䂓 大正10年代の裏町 (六日町)の古写真 ${ }^{39}$ によれば，魚屋の小店には，売台が置かれ，商品売買の場としても 利用されていた。

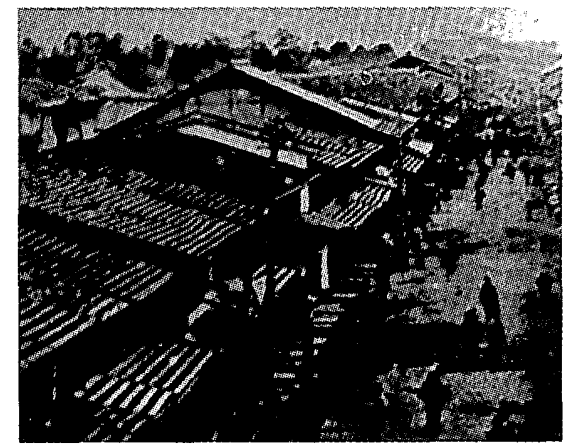

図 -4 明治 20 年代の表町の小店
その後，八戸の小店通りは，大正13年 (1924)の大火によりほとん どが焼失した。昭和初期の表町の十三日町の写真 ${ }^{40)}$ によれば，町 家前面の小店法失われ，二階屋前面は，軒の出の浅い庇に变わって いる。さらに焼失を免れた小店通りも，昭和 30 年 (1955)までに消墄 した"1。

以上のように八戸においては，明治・大正時代において，落し式 の小店通りが設けられ，小店先には，かけ障子が設けられていた。 その後，大正13年 (1924)の大火により小店通りのほとんどが焼失し， 娔失を免れた小店通りも，昭和 30 年(1955)までに消滅した。

\section{4)新潟における鹤木の障害物の撤去と権利形的}

新渴は，安政5年 (1858)の日米通商条約によって，開港される五 港の一つに定められた。明治元年 (1868)には，民政局が設置され， 明治2年 (1869)10月に開港した ${ }^{42)}$ 。

明治5年 (1872)には，楠本正隆が新潟県令として着任し，殖産興 業・文明開化・町村行政改革などとともに, 都市整備を開始した ${ }^{43)}$ 。 明治 22 年 (1889)には, 市制を施行した。

(1)公道としての雁不通り『改革叢書』 ${ }^{44}$ 明治5年 (1872)9月3日の

「市中庇下道敷之内卜可相心得之事」には，

市中庇下之儀，一般道敖/内卜可相心得事

但，庇下之儀八従前之通可成丈往来之妨害不相成様致シ，別 于掃除不急梯心付可申事

とあり，雁木は，公道と同等の通路機能が求められた。

2噼木の障害物の撤去と補图 楠本県令の新潟改革のひとつに道路 整備がある。道路の改修工事も実施されたが，着任早々に問題にし たのは，路上に物が置いてあることである ${ }^{45) 。 ~}$

『改革叢書』明治5年 (1872)7月の「市中心得書並教諭文同和解上 には,

町家二於テハ毎日銘々之軒下ヨ, 朝ハ五ツ時迄二タハ七ツ時迄 二必掃除致シ

とあり，猚木を清潔に保つように指示した。さらに同記録には， 五区内軒前ノ小便所 7 毀ツ事

是迄軒前見世前二小便所取設攵有之，見苦敷儀二付今度五区内 不残取毀チ，更二銘々之裏向工取設申付候事

とある。「五区内」とは，新潟町内のほぼ全域を指す。雁木には， 小便所が設けられるなど，好ましい状態ではなく，その撤去を行政

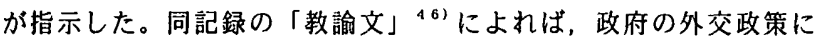
沿って，外国人に恥ずかしくない清潔な町とするため，䧹木の掃除 や，便所の撤去が指示されたことが分る。

さらに，明治6年 (1873)1月の『市中心得改定の伺』 ${ }^{471}$ には， 市中庇先ノ戸障子及庇内へ置台习設ヶ, 売物等 7 差置キ候儀, 廃止スへキ事

とあるように，雁木は，商品売買の場としても利用されていた。 同年3月4日の『新潟法令集』48)の「定」には，

当市中一般軒下へ戸障子或八羽目板, 壁等仕付ヶ有之分, 当月

限リ取払可申事

とあり，雁木の通路機能を確保するため, 往来を妨げる团い込みの 撤去を指示した。また同定には，

物干之義八表通り店先キ又八表庇，屋根等ニテモ決テ不相成候 事

とある。主屋屋根と表仳を区別した扱いから，明治6年 (1873)にお 
いて雁ホの形式は，落し式であったことが分る。

また，明治6年(1873)4月12日の『遠式睹違条例』49)「遀式罪目」

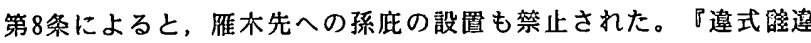
条例』は, 明治 13 年 $(1880)$ に, 全県に施行された。

明治11年 (1878) 7月に新渴町を訪れた, イギリス人の女性旅行家, イサベラ・バードが著した『Unbeaten Tracks in Japan』（『日本 の未踏の地』) ${ }^{50)}$ の挿し絵(図－5）には，町西端の西陶前通りにお いて, 二嘴屋前面の, 落し式䍜木と造り込み式雁木が描かれている。

さらに，䧹杂通りについては，「奥深いベランタが街路に治って ずらっと続いているので，冬になって雪が梁く筫ったときに，屋根 のついた歩道の役目をするよ うになっている」とあり,さ らににこの町では, (中略) ベ ランダの下をのろのろと歩く とあることから，雁木通りの 通路機能が保たれていたこと が分る。また，「町が改善さ

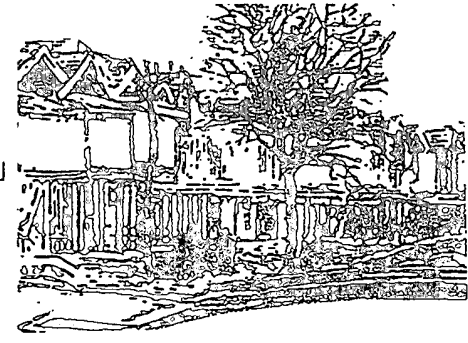
れたのも最近のことであり，图ー5 明治11年(1878)の新闆の椂相(掼写) 今では東京府知事になっている楠本正隆氏によって完成されたのは ほんの近年のことである」とある。よって，明治11年 (1878)までに は, 雁六通りも含めた都市整備が, 完了していたものと考えられる。 その後，明治13年 (1880)には，雁木の補修を，㢣察の管理下で実 施する方針に変わった。明治13年 (1880)2月20日の『新渴法令焦』 の「街路取締規則」第8条には，

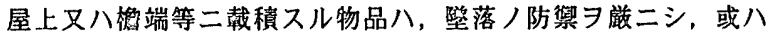
朽腐液敗シタル㴔・庇及七坦墙若クハ瓦石ノ壁落セントスル危 険ノ厥アルモノ八, 速二修補又八改造スヘシ, 尤モ巡㚗ノ注意 ヨ㤐侵二付スルモノハ, 時機二寄リ直二取除カシムルコトアル ヘシ

とあり，填れた雁木は，早速修理し，修理しない場合は撤去した。 さらに，明治15年 (1882)2月13日の『新渴県違檠罪』5'によよれ゙, 明治 13 年 (1880)の『街路取締規則』に違反した者や，䧹木において 鼬を引き，人々の往来を妨げる者は，厳罚に好した。『街路取締規 則』ならびに『新潟県違密罪』は，新潟に限らず，全県に施行した。 よって，䍜木の補修や，人々の往来の確保は，全県を対象に徹底さ せようとする行政側の意図が短える。

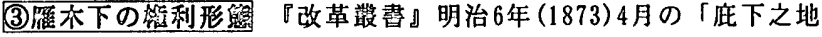
所取扱規則」の冒頭には，

当市街ノ地所公有私有之境界確定之儀, 此程中及布告䩤候処, 従前公地二取建有之建物取払候テハ難渋之趣二有之、今般戸長 用挂一同集議决定之上，庇下往来地拝借之儀願出候二付閏届侯 条，庇修理并道普請等ノ儀，戸長用挂工取扱申付候，此段可相 心得续事

とあり，「底下往来地（碓木下）」は公有地として認められながら も，その利用は届出の上追認した。さらに，同規則には，

建家土台真中ヨリ一尺五寸ノ地八，従前之通人民ノ私有卜ス， 其私有地ノ境ヨリ凡五尺通リ $习$, 併テ庇下往来之地卜定么, 而 シテ此往来ノ地所修理ノ費用トシテ，一些二付金五拾䤮宛 7 取 立, 町会所二於テ修理方可取扱事

とあり，建物の土台の真ん中から1尺5寸の土地は私有地とし，その
私有地の境から，およそ五尺をあわせて「庇下往来之地」と定め，そ この修理費用として1坪に付き，50銭がとりたてられた。これは， 碓木下を，私有地と考える住民側の判断と，その公共性を確保する ために公有地と考えたい行政側の判断の妥協が生み出した結累と考 えられる。また，住人の䍜ホの修理蜸用の負担は，同規則 ${ }^{521}$ によ れば，次の年から半減された。これは，䧹木通りの維持管理に関す る公共的性格を行政側が認めたためと考えられる。さらに，『新潟 町諧施設の治革』 ${ }^{53)}$ の「市街道路」の項には,

六年四月市中一般二低习修嬉シ

とあり，雁不の修理のことが示され，さらに「庇下之地所取扱規則」 には,

底八新旧ヨ論セス，端口高サ凡七尺ト定メ，総テー榚二改造ス ベシ

とあり，碓來の高さを揃えることを，整備の一環とした。

同規則 ${ }^{54)}$ によれば，䍜木の修理は，戸長や用挂 ${ }^{55)}$ の担当である ことが再度確認された。

以上の規則は，権利関係・規模・修理の担当など，雁木通りの維 持管理に関し，重要な点を網羅している。都市整備の早い時期に， 雁杢通りの政策について決定したいとする行政側の方針が窺え，雁 木通りに関する処置は, 都市整備における最も重要な課題の一つで あった。

(4)征交通りの短相 明治時代中頃の，町中心部の古町の古写真 ${ }^{561}$ (図ー6)によれば，落し式雁木と造り込み式雁木が確認できる。

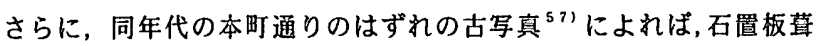
の, 落し式雁木が設けられていた。さらに雁木先には, 雨落が確認 でき，㕍木の前の道路上には，街奵が設けられていた。

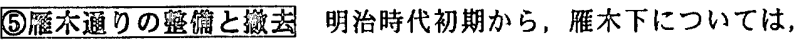
さまざまな規制が行われたが，不統一であり，交通の上からも，景 観の上からも問題が大きかった。そこで明治33年（1900）に，基準を 設けて規制を行うべきであるとの建議を, 当時の市会議長山崎利吉 が, 市長八木朋直に提出した ${ }^{58)}$ 。同年8月の建議 ${ }^{59)} に は$,

又世ノ開明二進ム二従七市街道路ノ規律ヨ正フスルハ勿論ナル 二, 事実却テ乱雑 道路 7 侵害シテ建物 設クルアリ, 其䣨状枚挙二遑アラス, 是 亦檠理ノ規定习設クル必要习認メタルナリ

とあり，㕍木を設けなかったり，町並みが見苦しかったことが分る。 さらに同規則には,

従来設置シ来リ夕ル䍜木（庇）ノ儀八全市調查ノ上, 今後尚必 要 7 認ムル場所卜不必要ノ場所卜ヨ区分シ（例セハ古町通何番 町ヨリ何番町迄雁木必要, 其他八不必要卜言フ如シ), 必要ノ 場所中設ナキ所八其土地ノ所有者, 若ク八地上権者二設置 $习$ 命 シ，其応セサル時八市二於テ設置シ费用习徵収スル事

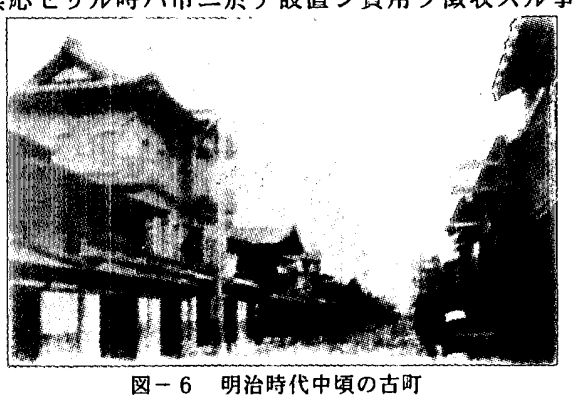


とあり，雁木の設置を土地の所有者に命じていることから，雁木は 私有地に建設するものとされていたことが分る。よって，明治33年 (1900)までには，泼倠木下は全て，私有地となったものと考えられる。 さらに，同建議によれば601，㕍木が必要と定められた場所に建 設されていた建物は，期限を定めて取り払うこととされた。さらに，

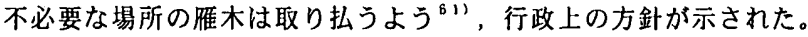

その後，明治41年 (1908)の大火は，市街の雁木通りのほとんどを 烧失させた ${ }^{62)}$ 。時の県警察部長，代田銈次郎は，雁木撤廃をとな

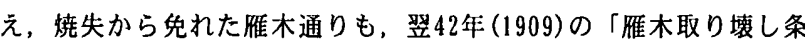
令」により撤去された。同条令は，新築家に倠木を設けてはならず， また，既存の惟木は，2年以内に取り払えという内容であった ${ }^{83) 。 ~}$

同条令の背景は, 明治41年 (1908)の大火の際，碓木下が延焼を早 める原因になったからだとされる。この条令は，新潟全県に対して 施行されたが，その反響は，積雪量の多い新潟県の中・南部の㕍木 通りを有した市街地に大きく，条令反对運動や暂願運動などが起き， 条令は徹底できなかった。新潟県津川町では，警官駐在所のある片

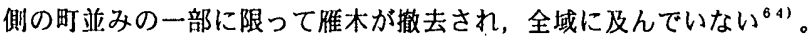
また，新潟県安田町においては，同条令について，旗野・斉藤二大 政敵を中心に，活発に議論が戦わされた ${ }^{65)}$ 。雁木通りの存否が， 極めて重要な問題であったことが分る。

さらに，この条例は，全県に対して施行されたものの，多くの町 では，部分的な実施に止まり，完全に実施されたのは，新渴市のみ であった。よって深雪地域の実状にあわないものと言え，住民も准 木通りの効果を十分に認識していたことが分る。

以上のように新潟においては，明治5年 (1872)に㕍木が公道と同 等の通路機能が求められた。明治6年(1873)には，雁木に戸障子・ 羽目板・壁など私的な囲这が多く，売台が圈かれるなど，住人によ り私的に利用されており，通路機能の確保を目的に，その撤去を行 政が指示した。さらに，雁木下の権利形態が，私有地1尺5寸，公有 地5尺と定められた。しかし，明治33年（1900）までには，碓朴下は， 全て私有地として追認された。

雁木の形式には，落し式と造り込み式が確認でき，明治6年 (1873) においては，落し式脽木であった。その後，造り込み式倠木が建設 されたのは，後年，䧹木下が全て私有地とされただと考えられる。

また，明治41年 (1908)の大火により，市街の倠木通りのほとんど が焼失した。さらに，焼失から免れた雁木通りも，翋42年 (1909)に 施行された「僱木取り填し条令」により撤去された。火災の際，倠 木通りが延焼を早める原因になったためである。

\section{5)長岡における落し式雁木と造り込み式雁木}

長岡は，明治21年 (1888)の東山油田の開発や，明治31年 (1898)の 信越本線の全線開通により，中越の中心都市として発達した ${ }^{661}$ 。 (雁木下の権利形息長岡の雁木通りは，近世において，表町では， 元和 3 年 (1617) 〜 年に私有地である屋敷地に建設された。

『延宝年中長岡町割絵図』 ${ }^{67}$ には，表町の道幅が7間，裏町が6 間半とある。裹町では，元文4年 (1739)に公儀地である道路上に建 設され ${ }^{68)}$ ，度芯年中 $(1865 \sim 67)$ の『長岡家中屋敷絵図』 ${ }^{69)}$ におい ても，延宝期(1673〜80) と比へ，道幅に変化はない。よって，表町 ・裹町の雁木下の権利形態は, 建設当初と同様の状態で，明治を迎 えたものと考えられる。

長風の难木通りは, 明治元年 (1868)から戦前まで私有地に建設さ
れていたとされる70)。よって，近世において公㒕地に設けられて いた裹町の焳木下は，明治元年 (1868)に私有地に取り込まれた。 (2)通路機能の磼固 私有地である倠木下の土地怯，課税の対象であ りながら，私用のために遮断する場合は，整察の許可を必要とし，

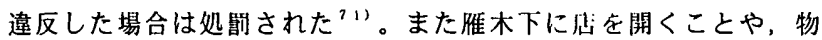
を㽞き去りにすることは，交通妨害として禁じられた ${ }^{23}$ 。通路と しての公共的性格を重視したためである。

(3)㕍木通りの景観 長岡の雁木通りは，明治43年 (1910)8月の，町 西端の千手横町の古写真 ${ }^{73)}$ (図一-7)によれば，造り这み式雁木が 確認でき，唯木の屋根は，石置板莫で，雁术先には小庇が設けられ ていた。

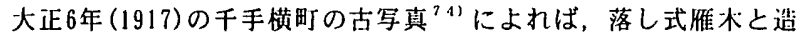

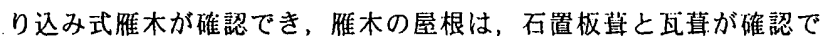
きる。同年の, 町西端の山田町 (千手横町の西側)の古写真 ${ }^{751}$ によ れば，落し式雄木と造り込み式傩木が確認できる。

大正時代の，町西端の文治町(遊郭通り)の古写真 ${ }^{28)}$ によれば, 瓦荤の落し式雄木が設けられていた。

以上の上うに長岡に拈いては，明治元年 (1868) 以来，睢木下は私 有地であった。明治時代においては，造り込み式雁木が存在した。

その後，戦災(昭和20年 1945)により倠木通りが焼失したものの， 戦災後の復興都市計画において倠木通りが新たに建設整唃された。

昭和21年 (1946) 2月10日付「新潟日報」によれば，同年同月に開 かれた都市計画協議会において，市は，住民の㕍木下の課税免除の 要求に応じ，(1)娔け跡の区画整理および道路計画の確立に当たって は，珮倠木は公有地（道路上）に建設してもらいたい。(2)私有地に㕍 木を建設する場合には，地租を免除してもらいたい，などの要望を 提出した ${ }^{71}$ 。この協議会の決定内容については不明だが，市側も 䧹木下の課税免除に積極的であった。

昭和 23 年(1948)3月8日に開かれた，長岡復興建設部参与会におい ては，㕍木は豪雪地として是非必要であり，幅員8間 $(14 \mathrm{~m})$ 以上の 道路には，公道上に㕍木通りを建設し，統一した景観を造るように 決定し実施された ${ }^{78)}$ 。その後，昭和 40 年代以降，表町の雁木通り がアーケードに変容し，蔓町の䧹木通りの一部が撒去され，軒の低 の浅い庇に变わった ${ }^{29)}$ 。

\section{6)高田における落し式雁木と造り込み式㕍木}

高田は，明治維新後，特殊な産業もなく寂れたが，明治 40 年 (19 07)に第十三師団が誘致され，新潟・長野両県から多くの人々が集 まり, 市街は活気を取り戻した ${ }^{801}$ 。

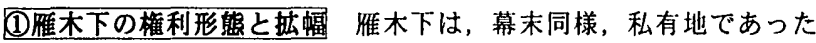
81)。維新後，倠木下の幅が2尺から4尺と狭い場合は，6尺に払幅し

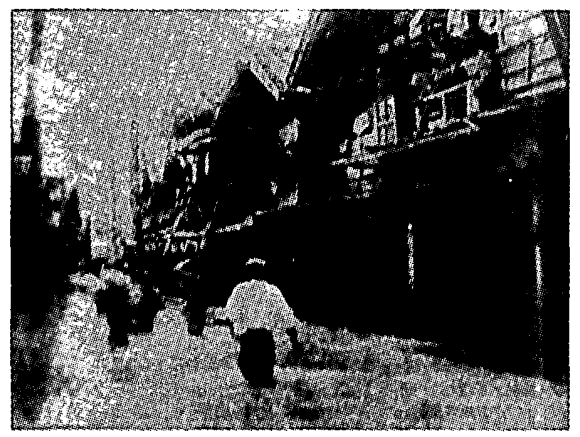

图一７㫜治43年 (1910)の千手横町 
た。また落し式がハイカラとされ，本町通りを中心に普及した ${ }^{821 。}$ しかし，明治42年 (1909)の「㕍杢取り壊し条令」のため，明治43 年 (1910)2月に五分一（現在の栄町）に開店した遊郭には，䧹木が 設けられなかった ${ }^{83)}$ 。

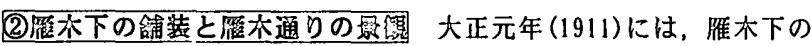
路面を舗装するように県条例が出され，本町通りにおいて実施され $た^{81)}$ 。大正元年 (1911) 頃の古写真 ${ }^{85)}$ (図一8)によれば，落し式䍜 木と造り込み式㕍朴が確認できる。大正4年 (1915)の本町 $2 丁$ 目の古 写真 ${ }^{86)}$ によれば，落し式雁木であり，雁木の屋根は，鉄板葛と瓦 葺が確認できる。また，同年の本町7丁目の古写真 ${ }^{87}$ によれば，瓦 荤の落し式㕍杢が設けられていた。大正初期の本町 $2 丁$ 目付近の古

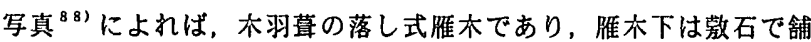
装されていた。大正6年 (1917)の今和次郎『見聞野帖』 ${ }^{89}$ によれば， 町東端の鎘屋町において，落し式脽木と造り込み式雁木が確認でき る。さらに雁不の屋根は，落し式雁木では，主屋同様，石圈の板莫 であった。

つまり，大正時代に おいては，落し式㕍木 と造り込み式雇木が存 在した。また雁木の屋 根は，場杢においては， 石置饭直であり，町中 心部の本町においては, 瓦莫・跌板惪・木羽葷 が確認できる。

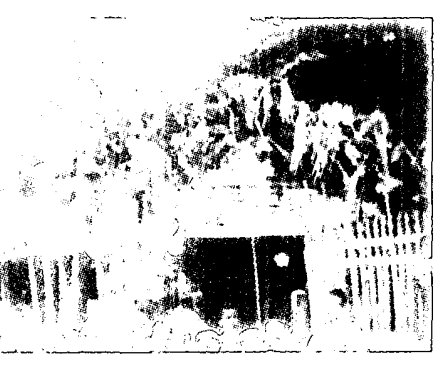

图-8 大正元年(1911)頃の様相

昭和8年 (1933)の写真 ${ }^{90)}$ によれば，鉄骨造の落し式䧹木が設けら

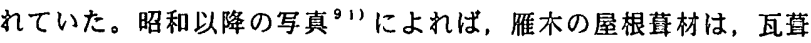
や鉄板葷が普及していた。

以上のように高田においては，維新後，㕍不下は私有地であり， さらに，本町通りにおいては落し式雁木が普及し，町はずれには， 造り込み式雁太が存在した。雁太下は，大正元年(1911)に本町通り においては，敨石で胡装された。さらに，昭和初期以降，雁木通り の一部に，パルコニーが設けられた。昭和 40 年代以降には，道路执 幅などにより，場末において，㕍木通りの一部が撤去され，軒の出 の浅い庇に変わった。

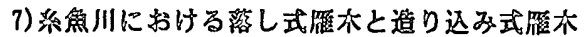

系魚川は，大正元年 (1912)12月16日に北陸線が開通し，市街は 活気を取り戻した ${ }^{921}$ 。

(1)明治期の蓝不の形式 明治11年(1878)の天皇巡幸を取材した，新 閏記者岸田吟穾の記録 ${ }^{931}$ によれば,

ひさし上の屋根石二通りずつ取り払ひ

とある。「ひさし上の屋根石」とあることから，雔木の形式は落し 式で，䧹木の屋根は，石置板葍であった。

(2)大正期の㕍不通りの原细 大正4年(1915)の大町通りの様相を古 写真 $^{94}$ にみると，雁杢の形式は落し式であり，雁杢の屋根は石置 板莫と，瓦真の両方が確認できる。さらに䧹木下は，影石によって 舖装され，雁木先から少し既れた位置に清が通っている。この淟は， 雨水の排水に利用された。

大正6年 (1917)の今和次郎『見開野帖』95)によれば，鉄砲町の 長屋前面に設けられた，石置板营の落し式雁木は，戸袋や建具が設
けられるなど，町家に取り込まれた。鉄砲町が町はずれであること から，人通りが少なかったためであろう。

さらに『見聞野蛅』（図一-9）には，町中の漁家の町家が4軒描か れている。いずれも妻入の二階屋前面に雁ホが没けられており，落 し式雁木の町家が2軒, 造り込み式雁木の町家が2軒である。雁木の 屋根はいずれも，主屋同様，石置板营であり，䧹不の前には，石積の 水路が設けられていた。さらに，造り込み式倠木の前には，小庇が 設けられていた。

以上のように糸魚川においては， 明治11年(1878)に，石置板荤の，落 し式雁不通りが設けられていた。大 正時代には，落し式雁木と造り込み 式䧹木が存在した。その後，昭和 40 年代までには，道路拡幅により，大 町。新屋町など町中心部において, 雁木が撤去され，軒の出の浅い仳に かわった。

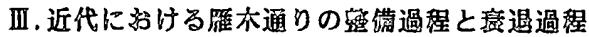

近代における各都市の陮木通りの整備過程と衰退過程を，時間軸 の上で咉討する（表一1）。

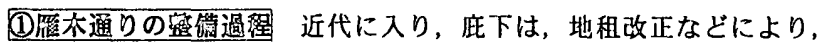
全国的に公有地化する政策がとられた。たとえば，大阪では，道路 境界の明確化を目的とした，明治4年(1871)の布達にはじまり，地 租改正，地券発行などを経て，それまで占有化されていた庇下(お

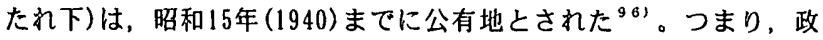
府は, 近世において, 当初公儀地であり, その後, 屋敷地にとりこ まれた底下を，近代以降，公有地として回復し，さらに公有地には み出して建てられていた家屋・庇などについては，いずれ公有地と する目的で，占有料や使用料を改收した ${ }^{97}$ 。

䧹杢通りの整備過程を整理すると，次の 4 事例となる。

(1)近世において公儀地であるが，占有化されていた雁木通りは，明 治初期において，便所や囲い込みの撤去が指示され，公有地とし て，本来の通路機能を回復した(弘前・青梪)。

(2)近世において私有地であったために，占有化されていた雁木通り

は，近代以降，行政により占有化が䙪じられ，私有地にもかかわ らず，本来の通路機能を回復した(長岡の表町)。また，明治初期 において，䧹木下か，私有地から公有地とされたことによりそれ まで占有化されていた睢杢の便所や囲い込みの撤去が指示され， 本来の通路機能を回復した。その後雁木下は，私有地とされたが， 通路機能は維時された場合がある(新潟)。似木通りの公共的性格 を，住民がある程度認めたためであろう。

(3)近世において公儀地であり，通路機能が保たれていた雁本通りは， 明治元年 (1868)に私有地となって以来, 占有化の傾向が現れはじ めた。しかし，行政により占有化は禁じられ，本来の通路機能を 回復した (長岡の裹町)。

(4)藅末以来，屋敨地にとりこまれながらも，通路機能が保たれてい た雁木通りは，明治期以降，私有地にもかかわらず，通路機能が 維時された。これは，雁不通りの冬期における利便性を，住民が 高く䛨価していたためと考えられる(高田)。 
以上のように，雁木通りは，明治初期において占有化されていた 場合には，通路機能の確保を目的とした整備が実施された。雁木下 が，公道と同等の通路機能が求められたためである。

いっぽう長岡では，戦後，新たに雁木通りが再整備されたが，昭 和 40 年代以降，赝木通りがアーケードに変容したり，雁木通りの一 部が撤去され，軒の出の浅い庇に変わった。

\section{(2)雁木通りの衰遍過程}

雁木通りの衰退消减の過程を整理すると，次の 4 事例となる。 (1)明治後期から大正期の大火により焼失し，雁木通りの一部が軒の 出の浅い庇に変わった(青森・八戸・新潟)。

(2)(1)大火の後に出された雁木撤去の条例により，防火の観点から

撤去され，軒の出の浅い底に変わった(青森・新晹)。

(3)戦災により焼失し，軒の出の浅い庇に変わった(青森)。

(4)戦後の都市計画による道路拡幅により衰退し，雁木通りの一部が， 軒の出の浅い仳に変わった (弘前・高田・糸魚川)。

以上のように，雁木通りは，明治後期から大正期では，防火の観 点から，戦後では，道幅の抾幅により，衰退消减した。これは，明 治後期から大正期にかけては，防災都市の建設を目指し，戦後は， 都市内交通を円滑にするために幅広の道路網を整備するなど，当時 の都市整備の目的に対応したものである。

(3)雁木の形式 近代における雁木の形式は，落し式と造り込み式で あり，弘前・青森・八戸・高田では，近世において建設されていた， 落し式雁木ならびに造り込み式雁木の形式が，近代以降も継承され た。また，秋田も同様の傾向であった ${ }^{98)}$ 。

いっぽう，新渴・長岡・系魚川では，近代に入り，造り込み式雁 木が建設された。公有地に雁木が建設されていた弘前・青森では， 造り込み式雁木が建設されなかったことから，新渴・長岡において， 造り込み式雁木が建設されたのは，雁木下が私有地であったことに 表一 1 近代における雁木通りの整備過程と衰退過程
対応したものと考えられる。

以上を踏まえ，雁木下の権利形態と雁木の形式を整理すると，次 の 2 事例となる。

(1)雁木下が公有地，落し式雁木 (弘前・青森)

(2)雁木下が私有地 $\rightarrow$ 造り込み式雁木(新潟・長岡・系魚川)

近代において造り込み式雁木は，雄木下が私有地であった場合に 限り，建設された。これは，灰木下が私有地であったため，落し式 䧹木の屋根上の占有化が可能であったためである。

\section{V.おわりに}

㕍木通りは，冬期間の歩行者用の通路機能の確保を目的とした， 都市施設である。

近世において建設された雁木通りは，明治初期に，公道と同等の 通路機能を求められ，整備された。よって近代以降も，碓木通りの 通路機能が維時された。

难木通りの整備過程は，明治初期において，公有地における雁木 通りを整薉し，本来の通路機能を回復した（弘前・青森・新潟）場合 と，その後に私有地における脽木通りを整備し，通路機能を回復し た(長岡の表町と裏町) 場合がある。公有地における雁木通りの整備 が、私有地に比べ早かったのは，公道と同等の通路機能が，私有地 に比ベ，逸早く求められたためである。

その後倠木通りは，明治後期から大正期の，大火や，大火後定め られた雁木撤去の条例により衰退消滅し，さらに戦災や，戦後の都 市計画にともなう道路拡幅により，衰退消隇した。

近代における雁木の形式には，落し式と造り込み式があり，近世 以来の雁木の形式が継承された。いっぽう，近代に入り，膺木下が 私有地であったことにともない，造り込み式雁木が建設された場合 がある。

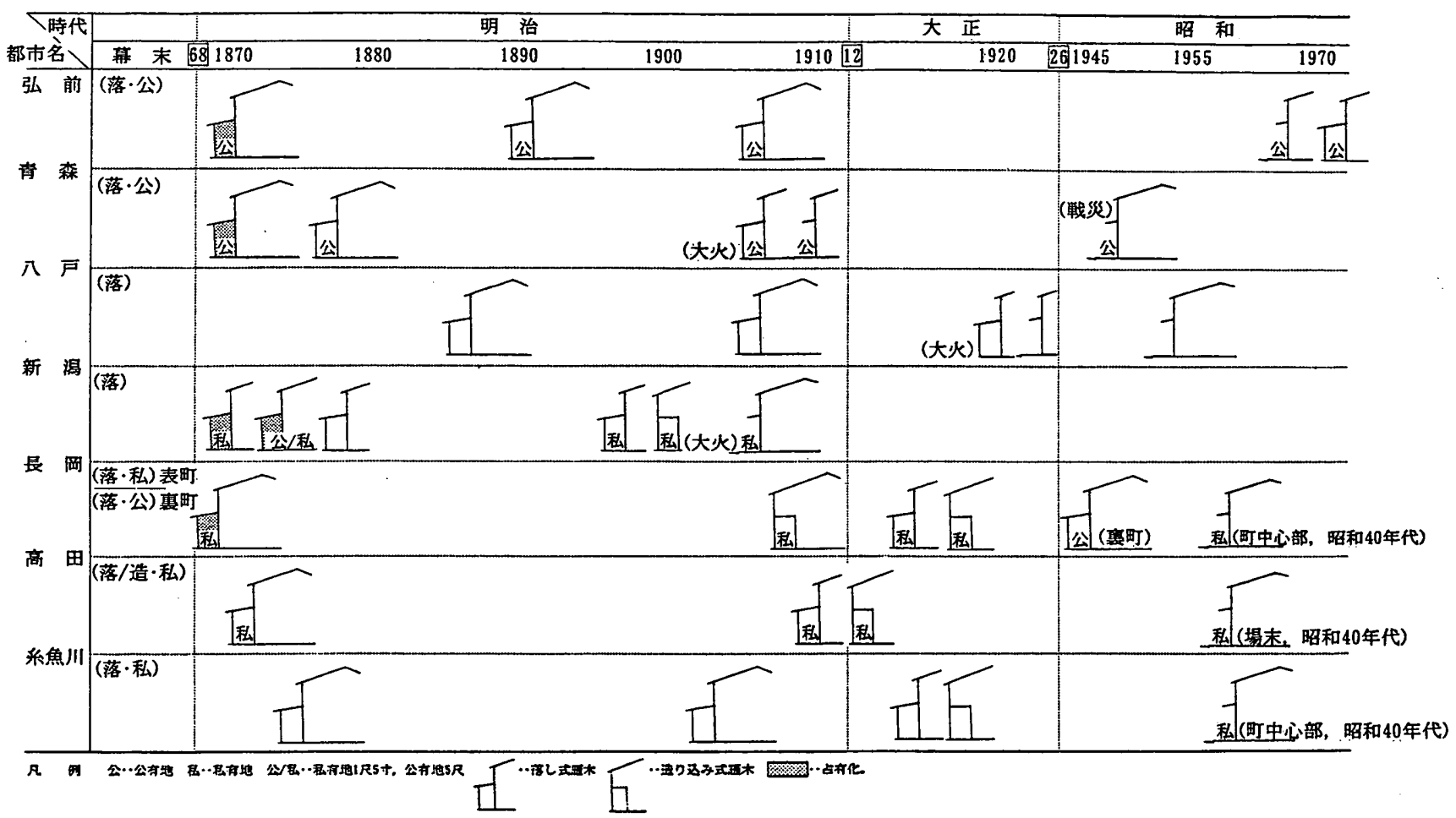


注)

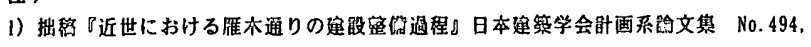
1997年4月。

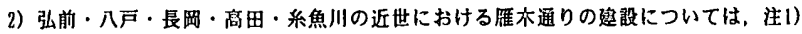
前揭界文降照。

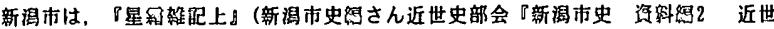

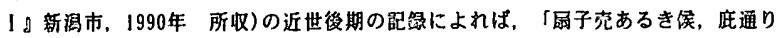

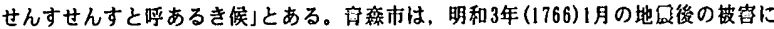

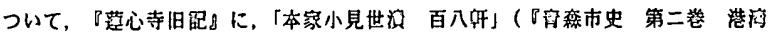

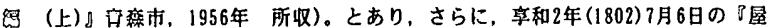

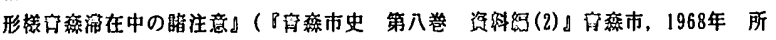

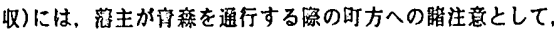

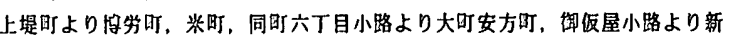
可期仮屋

の叮において,

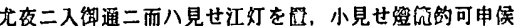

弘前・八戸・長田・高田・系魚川は，雁杢通りが建殷された代表的な俦下朾であり，

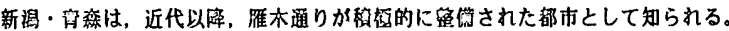

3）底・的・的・年下・小見世・小店は，本文中で出典を示す。

4) 注1)的揭的文帘照。

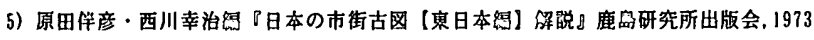
年。

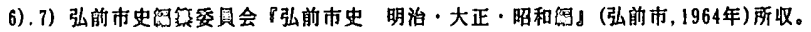

8) 注6)前揭可。

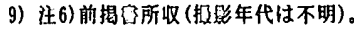

10)師团得较には，家疾とともに移り住む者が多かった。

11) 注6)前揭行。

12)注6)前揭的所。

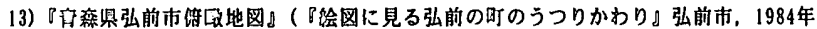
所收)。

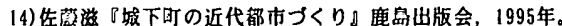

15)住5)前揭已に示される。

16)氏家武『日本における陮不通りの地理学的研究』私家版，1976年に示される。

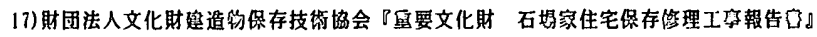
石谒消阔，1982年。

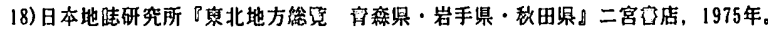

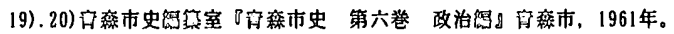

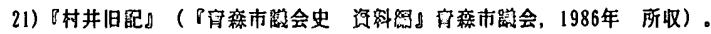

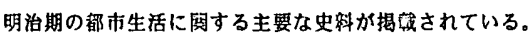

22)注21)的揭『村井旧觖』。

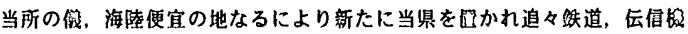
等彻虽け人民便利の道を開きなされ续御趣旨につき

とあり,さらに,

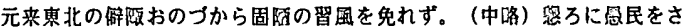
として顾俗を洗脱せしむべし。

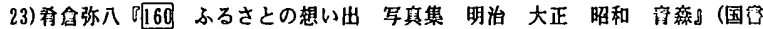
刊行会, 1980年)所收。

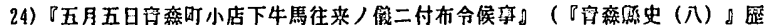
史图行社, 1971年 所收)。

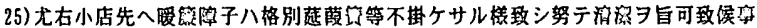

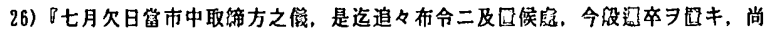

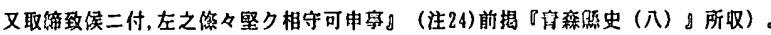

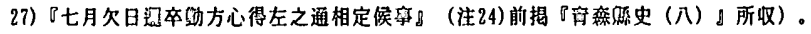
第十五像市中往来左右游ヨリ前へ庇

28)注23) 前揭保所叹。

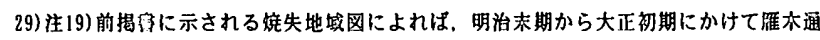

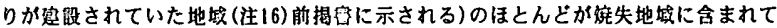
いる。

30) 32) 注 19) 前揭级。

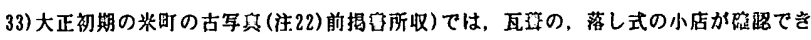
ることから，明治43年(1910)の大火後，得是されたことが分る。

34)注16)前揭约。

35) 注.18) 前捍行

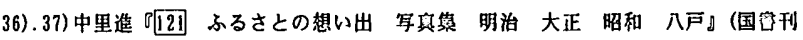
行会, 1980年) 所収。

38)高盛成侑・三浦忠司『南部八戸の诚下叮』伊吉它院, 1983年。

39) - 40)注36)前揭绝所取。

41) 注 16) 前揭员。

42) 拄5) 前揭员。

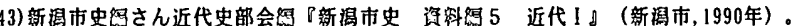

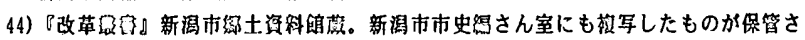

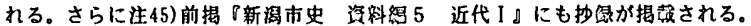

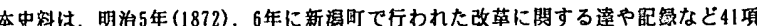

目を、明治10年代に新潟区の役人であった、早川清作がまとめたものである。

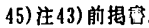

46) 注44)前揭首。

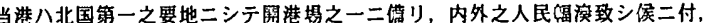

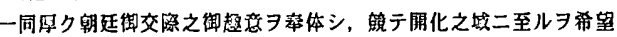

とあり,さらに、

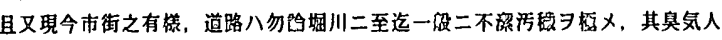

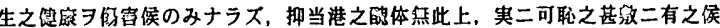

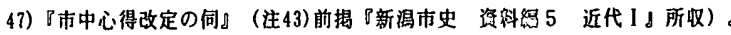

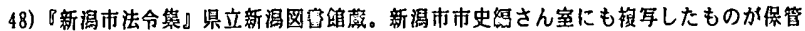

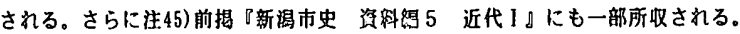

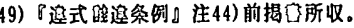
往索又八下水外河中等工家作, 并二孫底等

50)イサベラ・バード PUnbeaten Tracks in Japan」(8日本の圭箈の地』)

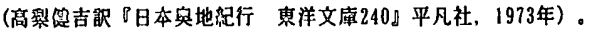

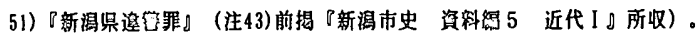

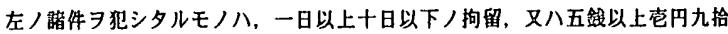
五路以下ノ科科二処セラレルヘシ

三，衔路取镜規則二遥背シタル者

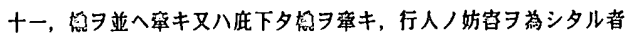

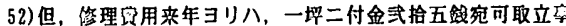

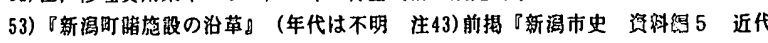
I \& 所仅）。

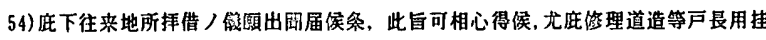

55) 叮会所の役融。

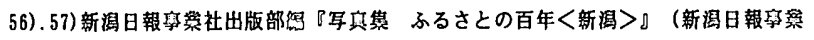

社, 1980年) 所収。

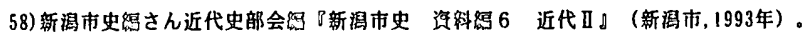

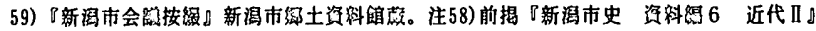

にも一部所叹される。

60)注59)前揭日。

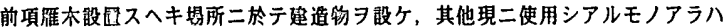
期限ヨ定メテ取払ハシメ，若シ取払ハサル時ハ市二於テ取払へ其空用ヨ钽取ス ル芦

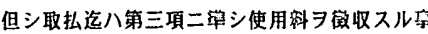

61)注59)前揭保。

雁本必要ナキ場所二於テ膺木ヨ設ケアルモノハ期限ヨ定メテ取払ヨ命シ，若シ

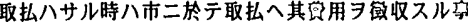

但シ取払迄八第三項二梁シ使用科习箯饨スル字

62)注16)前揭量。

63)高田市史绿集委員会『离田市史 第一巻』高田市役所, 1958年。

64)注16)前揭㝵。

65) 氏家武『わが国における“がんき(こみせ)通り”の地理学的研究(第 5 報)－消负都 市についてー』立正地理学会「地域研究」第14号，1971年。

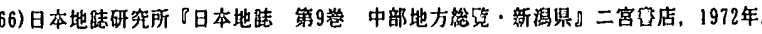

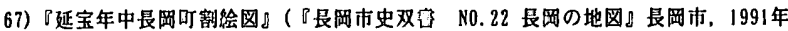
所收)。

68) 住1)前揭㧱文参照。

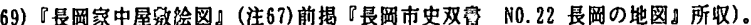

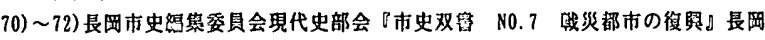
市, 1990年。

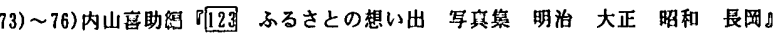
（国新刊行会, 1980年）所収。

77). 78) 注70)前揭客。

79) 注 16)前揭字

80) 注5)前揭程。

81) 84)注63)前揭 [?.

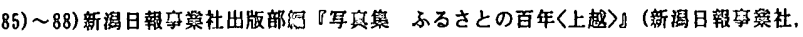
1982年)所收。招硫坦所は不明。

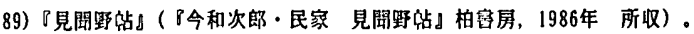

90). 91) 注85) 前揭院所収。

92)系魚川市役所『糸魚川市史6』糸魚川市段所，1984年。

93) 注92) 前揭嘼所収。

94)下村省一·经子治『目てみる上越・系魚川の百年』（绿土出版社，1992年）所收。

95) 注88)前揭诘。

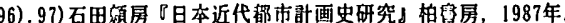

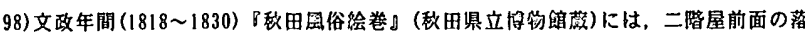

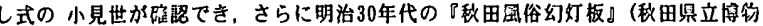

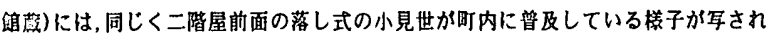
ている。 